\title{
Observations on the Formation and Breakdown of the Oxidized Microzone at the Mud Surface in Lakes ${ }^{1}$
}

\author{
EvILLe Gorifam ${ }^{2}$ \\ Freshwater Biological Association, Ambleside, England
}

\begin{abstract}
Fvidence is presented indicating that the winter thickness of the oxidized microzone at the surface of lake muds may depend upon turbulent displacement of the uppermost sediments into the overlying acrated water, as woll as upon the reducing power of the sediments themselves. It is also suggested that this winter oxidized layer may disappear mainly from the surface downward, owing to the greater oxygen consumption there brought about by decomposition of sedimented plankton. Lastly, evidence for a final evolutionary phase of lake sterility, due to development of extremely reducing conditions in the bottom mud, is examined and rejected.
\end{abstract}

In 1942 Mortimer, in his classic study of the exchange of dissolved substances between mud and water in English lakes, described the existence at the mud surface of an oxidized microzone, which he showed to exert a pronounced influence upon the exchange of substances across the mudwater interface. This oxidized layer ho believed to be maintained by molecular diffusion of oxygen into the mud, to a distance depending in winter almost wholly upon reducing power (or oxygen demand) of the sediment in any given lake. However, in the course of studies on Esthwaite Water, the most "eutrophic" of the series examined by Mortimer, the writer has come to believe that the reducing power of the mud is of relatively less importance in determining the winter thickness of the oxidized layer than the degree to which turbulence stirs the mud up from the bottom and into the aerated water column above.

If "the presence of an oxidized microzone throughout the entire year in some

1 It is a pleasure to thank Dr. F. R. Hayes, Mr. Byron Reid, Dr. J. W. G. Lund, Dr. Harold Mundie, Miss V. G. Collins, and Dr. C. II. Mortimer for many helpful discussions of these problems. I am also much indebted to Mr. G. J. Thompson and the laboratory staff of tho Freshwater Biological Association for collecting the core samples.

${ }^{2}$ Address from September: Botany Department, University of Toronto, Canada. lakes, and its disappearance seasonally in the deeper parts of the basin in others, may woll be the most important dichotomy in the chemical classification of lakes" (Hutchinson 1957), it would secm of considerable interest to establish the factors controlling its thickness. Evidence for the "turbulent displacement" hypothesis will now be presented, with in addition some obscrvations upon these layers in other lakes, and upon the breakdown of the oxidized layer of surface mud in Esthwaite Water during summer stratification.

EFFECTS OF TURBULENCE UPON THE MUD SURFACE IN ESTHWAITE WATER

From December 1954 to November 1955 the undisturbed mud surface in the deepest part of Esthwaite Water was examined weekly in four cores taken N, S, E, and W of a fixed buoy with the Jenkin surface mud sampler (Mortimer 1942, Fig. 22). During the first six months a surface layer of rather orange-brown mud could be very clearly and sharply distinguished from the blackish-brown or black mud below, which owed its dark color to precipitated ferrous sulphide. The depth of the orangebrown surface layer, averaged from four points around each core, varied from 6 to $38 \mathrm{~mm}$, averaging about $20 \mathrm{~mm}$. There was not a great deal of change over the whole six months, depth averaging $18 \mathrm{~mm}$ in December, and $22 \mathrm{~mm}$ in June when the 
lake was stratified but with oxygen still present in the hypolimnion. In this connection Collins (1956) records that the topmost $20 \mathrm{~mm}$ of Esthwaite mud contains an acrobic bacterial flora in winter. It may further be noted that special samples taken at the end of the stratification period, after the surface mud had had a summer in which to consolidate, revealed that the top $1.5 \mathrm{~mm}$ or so of mud were less than half as dense as succeeding $20 \mathrm{~mm}$ sections down to $95 \mathrm{~mm}$ (dry weight of mud $=0.06$ $\mathrm{g} / \mathrm{cc}$ as against $0.15 \mathrm{~g} / \mathrm{cc}$ ).

If this surface orange-brown layer is the result simply of molecular oxygen diffusion into the mud to a depth depending upon its reducing power, one would expect anaerobic cores to develop such a surface layer upon aeration of the overlying water. To test this hypothesis several cores were taken from Esthwaite Water during September of 1955 and 1957 after the mud surface had become completely reduced and black in color, and these were subsequently acrated in the laboratory without any disturbance of the mud surface. (In 1955 this was accomplished by bubbling air through a U-tube suspended near the bottom of the water column, while in 1957 circulation was provided by running a heating element down one side of the water column in an open core tube, as suggested by F. R. Hayes in a private communication.) Some cores were stored at room temperature, others at about 7 and $12^{\circ} \mathrm{C}$, for periods lasting up to four months; but in no case was the orange-brown surface layer characteristic of winter conditions produced. While an orange floc of ferric hydroxide began to accumulate upon the mud surface following the introduction of oxygen, this seldom gave a blanket of more than a few mm thickness, and the mud beneath remained quite black in color. As time went on the orange surface deposit tended to consolidate somewhat, while the mud beneath generally showed little change, except in places where tubificid worms introduced air down their tubes and produced an orange channel into the top $10-20 \mathrm{~mm}$ of mud. (In one exceptional case, in a core stored at about $12^{\circ} \mathrm{C}$ and containing a larger number of tubificid worms than usual, the surface black mud gradually turned brown after about thrce months due to their activities, but the brown layer so produced was very irregular in depth.) Only when the topmost mud was actually stirred up into the aerated water and redeposited did a thick brown oxidized layer appear over the blackish reduced mud, suggesting that in the lake as in the laboratory turbulent displacement is necessary to its formation. That it cannot be wholly the result of fresh sedimentation is indicated by the studies of Tutin (1955), who records deposition of only about 0.05 mm per week in Windermere over the year 1940-41, and also similar rates in Esthwaite for the period March 12-June 6, 1941 when the two lakes were compared. Moreover, she observes that some of this sediment appears itself to have been swept off the bottom (see later).

At about the time of the 1955 experiments, the effects of the autumn overturn were being followed in the wcekly cores. Within a week of its completion a slight (ca $1 \mathrm{~mm}$ ) surface floc of orange ferric hydroxide was observed. The following week three of the cores showed little change, while the fourth exhibited a thick $(5-10 \mathrm{~mm})$ blanket of orange-brown floc. This last core was taken north of the buoy, where the orangebrown layer was most often thickest in winter, and it was inferred that this site was probably a slight depression which tended to collect materials swept up from the mud by turbulence.

A more direct indication of turbulent stirring was observed during the overturn period itself. At an early stage in the breakdown of the thermocline a dense blanket of grcyish-green algal filaments (Melosira italica subsp. subarctica) was observed to accumulate and cover the surface of the mud in the decpest part of the lake for about two weeks. Then, on October 18, a gale combined with heavy rain succeeded in completely overturning the lake, and within 24 hours this blanket was entirely dispersed, and remained so for the fortnight following, after which observations ceased. Iund $(1954,1955)$ has shown that 
Melosira, whose filaments (averaging about $0.3 \mathrm{~mm}$ long) exhibit a rapid sinking rate whenever the lake stratifies, is frequently swept up from the mud in great quantities, and indeed appears to depend for its existence upon the regular stirring up of the mud surface at overturn, leading to turbulent suspension of the algal filaments during the period of isothermal circulation. Collins (1956) and Mundic (1956) also report phenomena which may be construed as evidence that bacteria and chironomids are swept up from the bottom deposits at the same time.

In 1957 the process of establishing an oxidized surface layer in the mud was followed much farther. Observations began on Septembor 2, when Fisthwaite Water was still stratified. At this time the mud was strongly blackened by ferrous sulphide from the surface to an average depth of about $15 \mathrm{~mm}$, below which the color was a more blotchy blackish-brown for 20-30 $\mathrm{mm}$ and then a more solid black again beneath. A dense concentration of bluegreen algac (Microcystis and Coelosphaerium) was noticed in the water overlying the mud, and a thin (1-2 mm) band of these green colonies, which were easily visible to the naked eye, was scen at about 5-10 $\mathrm{mm}$ beneath the mud surface. 'This suggested some degree of turbulent disturbance of the mud surface even before the autumn overturn, for it is unlikely that these cells could become stratified under the mud in any other way. It is also improbable that the band could bo the result of downward smearing in all four cores, since the top $10-20 \mathrm{~mm}$ of deposit is very loose and floceulent, and visible smearing has only been observed in the deeper and more compacted horizons of these cores. Moreover, later examination of vertical sections from frozen cores revealed that these algae did in fact become mixed well into the sediment, thus confirming the conclusions reached eurlier from examination of the mud visible through the sides of the core tubes.

On September 10 the bottom water in Esthwaite became acrated again. By the next sampling date (September 16) the upper blackish layer, which on this occasion averaged $17 \mathrm{~mm}$ deep in the four cores, was blotehed with flocculent orange ferric hydroxide, and the tubificid tubes usually present in these cores were also bright orange with this material. Green algal colonies were also observed to be mixed throughout the loose upper layer. By the following week there was less ferric hydroxide in the surface black mud, suggesting that reduction processes were more than balancing the entry of fresh oxygen. However, by September 24 the lake had become completely isothermal, and on September 30 the surface layer was again a mottled mosaic of black and orange patches in its upper part, with green algal colonies throughout, although it may be remarked that the very bottom of the surface horizon was still fairly solid black with ferrous sulphide.

On October 7 the uppermost loose mud (averaging on this occasion $11 \mathrm{~mm}$ deep) was becoming a fairly uniform orange-brown but with flecks of black forrous sulphide throughout, and, at the very bottom of the layer, a tenuous interrupted band of black ferrous sulphide remained witness to the carlier phase of complete reduction. This state of affairs persisted until early November, when the flocculent surface layer was observed to be almost wholly orangebrown in color, with only scattered flecks of black ferrous sulphide, and no band at the bottom. At this time its thickness averaged about $14 \mathrm{~mm}$.

The mixing of orange flocs of ferric hydroxide, and especially of algal colonies, deep into the uppermost black horizon at the onset of autumn circulation strongly suggests turbulent churning of the surface mud by the overlying aerated water. The observational evidence is squarely against a gradual decpening of the oxidized microzone in response to molocular diffusion of oxygen, and all in favor of sudden turbulent displacements bringing about penetration of oxygen nearly to the bottom of the surface floceulent layer, and also the distribution of algal colonies from the overlying water well into the top 10-20 mm of mud. Another point in favor of this hypothesis is the fact 
that tubificid tubes (easily noticed after overturn becausc of their bright orange sheaths extending from above the mud well down into the black horizons of ferrous sulphide) often became truncated at the boundary between orange-brown and black mud, so that only the deeper part remained.

These tubificid worms must disturb the sediment in Esthwaite Water by working the surface layers and casting their faeces into the overlying water, but storage $\mathrm{cx}$ periments in the laboratory have not shown their activities to be very significant. Nor, according to the laboratory observation, is the production of gas bubbles deep in the anaerobic layers of mud very important in this connection although it occasionally brings about some disturbance in peaty bottom deposits.

A final point with regard to Esthwaite Water may be made from Mortimer's observation that after overturn in 1940 "the thickness of the oxidized layer was subject to considerable fluctuations. During a calm spell in December it consisted only of a surface scum containing ferric hydroxide, and it was again almost destroyed during stagnation under ice from 3 January to 15 February 1941." Since oxygen concentrations just above the mud rose steadily throughout December it seems strange that the oxidized microzone should almost disappear, unless we assume that the calm weather, by preventing the mud from being occasionally mixed with the overlying aerated water, was responsible for the phenomenon. We may explain the neardestruction of the oxidized layer during stagnation under ice in a similar way, although in this case oxygen data are lacking and we have to rely on the high redox potentials $(0.5 \mathrm{~V}) 10 \mathrm{~mm}$ above the mud as evidence for the presence of well-aerated water there.

\section{EVIDENCE FROM OTIIER LAKES}

An indication of the influence of turbulence upon the bottom deposits in Windermere is given by Tutin (1955) in her paper on the cycle of sedimentation in the North Basin. She observed a marked decrease in sedimentation during August and Septem- ber 1941, when stratification was most stable, followed by a sharp risc in early October to levels comparable with those maintained during the entire period of isothermal circulation. Evidence is provided that this October risc was due to the occurrence on September 30 of the first autumn gale, which stirred up material from the bottom above the thermocline and redistributed it partly to the deeper waters. She further points out that while freshly collected sediment is usually olive-brown in color, and only changes to dark brown and more compacted floceuli upon storage, on several occasions (especially at overturn) the fresh sediments had this darker and more "mature" appearance, suggesting that they had been swept off the bottom and redeposited in the sediment traps above.

Another picce of evidence suggesting turbulent displacement of the mud surface in this lake is Mortimer's statement that the thickness of the oxidized microzone was doubled after the autumn overturn in 1940 . Since oxygen concentration just above the mud was fairly high before the lake becamc isothermal (about $9 \mathrm{mg} / \mathrm{L}$ ), and only rose by a little over 20 per cent (to $11 \mathrm{mg} / \mathrm{L}$ ), it seems more reasonable to suppose that turbulent displacement was the agent responsible for this sudden descent of the oxidation-reduction interface.

Yet a further finding of Mortimer's may well be explicable on the same grounds. In measuring electrical conductivity (an indication of total dissolved ions) down two series of mud cores from Windermere North Basin, one taken at the end of summer stratification (A), and the other at the end of the circulation period (B), he recorded distinctly lower values in the latter case at comparable depths in the cores. The two curves are shown in Figure 1, from which it is evident that they are very similar in appearance. Indeed, it might easily be imagined that the curve for the end of the circulation period (B) represents the earlier gradient (A) somewhat less steep, and displaced slightly downward, so that its origin lies well within the mud rather than near its surface. Such a downward displacement could well result from turbulent disturbance 


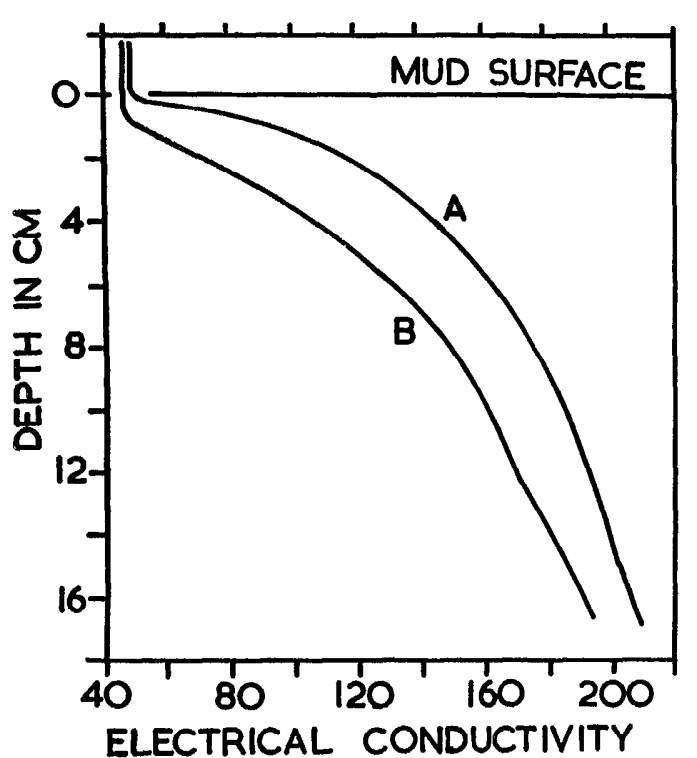

$K_{18} \cdot 10^{-6}$

Fig. 1. The relation between electrical conductivity and depth in surface mud cores from Windermere North Basin, (A) at the end of stratification, and (B) at the end of isothermal circulation (after Mortimor 1942).

of the mud surface, and the fact that in curve (B) the conductivity of the uppermost mud is the same as that in the water column above strongly suggests that it has actually been mixed with the overlying water and in this way has lost its excess of ions diffusing from below.

So far we have dealt with both the decpest and the shallowest of the five bodies of water investigated by Mortimer, and it remains to see whether any evidence for turbulent displacement can be gathered from the lakes as a group. Two suggestive features of Mortimer's earlier work descrve consideration in this connection.

The first is the pattern of redox potential distribution in the muds, which is illustrated in Figure 2 for Esthwaite Water and Ennerdale Watcr, which give the two extremes of winter redox profile, and for Crummock Water, from which the only summer profile was obtained. The most interesting feature of the winter curves is that they do not show the gradual decline of potential from the mud surface which one would expect if oxygen penetration into the mud were due solcly to molccular diffusion. On the other hand, the presence of potentials well within the mud which are just as high as those in the overlying water argucs strongly that there must be some turbulent mixing involved, leading to the penctration of the overlying aerated water right into the uppermost horizons of the mud. If the above argument is correct, we can then estimate roughly the depth of effective turbulent displacement as being the depth to which redox potentials as high as those in the water (approximately $0.5 \mathrm{~V}$ ) are found in the mud. The values thus obtained (very crudely, from Mortimer's Fig. 43) are as

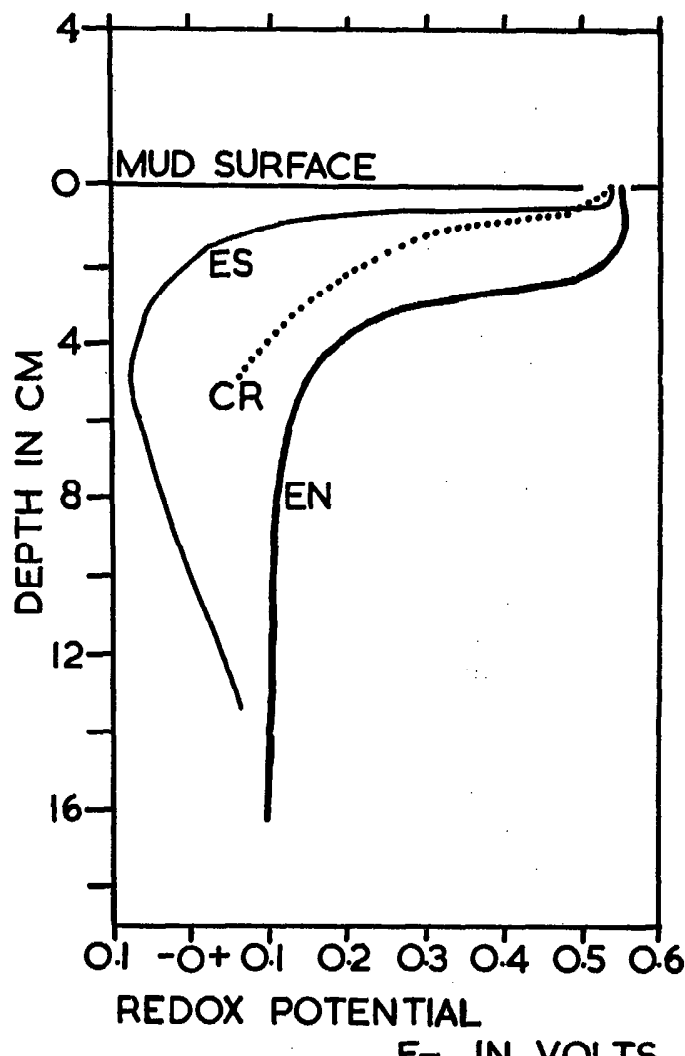

$E_{7}$ IN VOLTS

FIG. 2. The relation between redox potential and dopth in surface mud cores from Esthwaito Water (ES) and Innerdale Water (LN) at the end of isothermal circulation, and Crummock Water (CR) at the end of stratification (after Mortimer 1942). 
follows: Crummock Water $4 \mathrm{~mm}$, Esthwaite Water $5 \mathrm{~mm}$, Windermere North Basin $6 \mathrm{~mm}$, Windermere South Basin $11 \mathrm{~mm}$, and Ennerdale Water $20 \mathrm{~mm}$. Of these, the value for Crummock Water represents late summer conditions, and so is not comparable to the rest. However, the Crummock redox/depth gradient is of great interest for this very reason, in that it alone of the five curves exhibits the gradual decline of potential from the mud surface which is to be expected if only molecular diffusion of oxygen is involved; and it alone represents a time when turbulent disturbance of the mud might be expected to be minimal.

In connection with the depths of turbulent stirring estimated above, it may be remarked that the further distance into the mud between the $0.5 \mathrm{~V}$ and the $0.2 \mathrm{~V}$ isovolt may be taken as a rough indication of the relative effectiveness of molecular oxygen diffusion in aerating the various lake muds. For this property the respective values are: Esthwaite $2 \mathrm{~mm}$, Windermere North Basin $5 \mathrm{~mm}$, Windermere South Basin $6 \mathrm{~mm}$, Crummock Water $18 \mathrm{~mm}$, and Ennerdale Water $20 \mathrm{~mm}$. The trophic scries obtained by Mortimer is thus seen to be maintained, although the method of measurement is changed.

The second feature of Mortimer's results bearing on the problem of turbulent mud displacement is his finding that the exponential inerease of electrical conductivity downward, which he noted as characteristic of all the lake muds (see his Fig. 46), fails to hold near the mud surface. Mortimer explains this as being due to ion adsorption in the oxidized layer, but this conclusion is open to question (Gorham in preparation), and turbulent disturbance of the oxidized microzone may well provide an alternative explanation.

$\Lambda$ last point to be noted about these redox curves is that in the middle horizons around $50 \mathrm{~mm}$ the Ennerdale potential is much less than the others (see Mortimer's Fig. 33). This is probably connected with the virtual absence from Fnnerdale cores of any black staining by ferrous sulphide, a compound found only in strongly reducing environments, and observable in some quantity in all the other cores, especially in listhwaite Water.

A final piece of evidence for turbulent stirring of the mud surface as a general phenomenon may be found in Lund's (1954) report that the life cycle of Melosira italica subarctica, common in at least seven of the larger lakes in the English Lake District, depends for its existence upon re-suspension from the bottom deposits, to which it sinks rapidly in calm weather.

From the observations and experiments described above, it seems inescapable that turbulent displacement plays an important role in establishing and determining the winter thickness of the oxidized microzone at the surface of the mud in Esthwaite Water, and probably in the other lakes as well. If so, this property must be controlled by a complex of interacting factors: some morphometric and affecting turbulence (e.g., basin size, shape, and exposure), others edaphic and affecting oxygen diffusion (e.g., texture, density, and permeability), and yet others biological, and influencing the reducing power of the mud (e.g., the nature and amounts of organic residues produced in the lake and entering it from outside, and also the nature and amounts of the organisms inhabiting the mud). In the light of this complexity, the correlation between thickness of the oxidized microzone in winter and areal rate of oxygen absorption in summer seems most remarkable, and deserving of further investigation. It is hoped that this correlation may be reexamined, together with the factors controlling turbulence at the mud surface, in the near future, when the underwater camera and current meter now being constructed in this laboratory should prove of great value.

BREAKDOWN OF THE OXIDIZED SURFACE IAYER

The thickness of the oxidized microzone was believed by Mortimer to decrease from below upward as thermal stratification progressed. However, observational evidence from Esthwaitc Water again suggests otherwise. During 1955 in Esthwaite Water, thermal stratification began in April, and oxygen stratification by the beginning of 
May. However, the boundary of the upper brown mud at about $22 \mathrm{~mm}$ remained very clear until well on into June. By June 15 a slight orange floc was observed to develop in bottom water samples on standing for a few days in the air-evidence that ferrous iron was diffusing out of the mud surface into the water above, which still contained considerable amounts of oxygen. It was also noticed on this date that a great deal of Melosira had fallen onto the mud surface, and in the cores of the following week a thin black layer had formed at the mud surface beneath this algal mat. Presumably ferrous sulphide had precipitated there duc to the intensity of algal decay.

This was the last week that Hydra appeared on the mud surface. During the winter a few were observed in most weeks, and occasionally half a dozen or so occurred in a single core, but during May they were seldom seen. On June 28, when more Melosira had fallen together with a mass of dead Daphnia from the zooplankton peak a short time before, the surface black layer was found again, and some flecks of black had begun to appear in the brown mud beneath, whose lower boundary was becoming difficult to distinguish. A test of the overlying water in these cores with dithizone gave no coloration, but on July 5 a pale pink tinge characteristic of manganese was noticed, and by July 12 this color had become much stronger. On July 19 in mudwater cores that had stood overnight a heavy orange floc appeared at the mud surface, which is evidence of intense ferrous iron mobilization there at this time. Meanwhile the brown surface layer became much more spotted with black ferrous sulphide, especially toward the surface; and in midJuly, when the bottom water had become completely anaerobic (modified Winkler, V. G. Collins, private communication), the boundary of the brown layer was no longer distinguishable.

These black flecks presumably represent local centers of intense reduction, most likely around organic debris; and the heterogeneity thus revealed within a given level probably accounts for the great difficulty experienced by Miss V. C. Collins (private communication) in getting reproducible redox potentials in the upper layers of summer cores from Esthwaite Water. It may well be that turbulent re-distribution of the upper mud smooths the winter potential/depth curves shown in Mortimer's Fig. 4:3, by mixing and aerating this variably reducing layer of surface mud.

By early August a layer of 5-10 mm of very black mud had accumulated at the surface in two cores, and in early September an even thicker black layer of about 10-20 $\mathrm{mm}$ developed in all cores. In addition it was noted that much less orange floc precipitated when the core water was left open to the air, suggesting that most of the ferrous iron was by that time precipitated as ferrous sulfide and less easily diffusible.

These results indicate that reduction of the wintor oxidized layer does not proceed mainly from the bottom upward, but from numerous sites within the layer and particularly at the mud surface, where the presence of abundant organic remains following the peaks of phytoplankton and zooplankton provides a stimulus for bacterial oxygen consumption.

A last point to be remarked is the possibility, mentioned by Mortimer, that intensive reduction of bottom mud may lead to a phase of lake sterility, associated with precipitation of most of the iron as ferrous sulfide. This idea appears to be taken over from Misra (1938), whose studies of small local areas along the shores of Esthwaite Water and Windermere revealed occasional bare patches of mud with a relatively high ignition loss. These were claimed to be deficient in adsorbed bases but rich in adsorbed hydrogen ions, so that the base saturation of the soil colloids was very low (5-10 per cont). Since these same muds wore reported as having $\mathrm{pH}$ values of around 6 , it scems most unlikely that the base deficiencies reported are real. The present writer (Gorham 1953) has obtained much higher base-saturation percentages (70 per cent or more) from both black and brown patches of bare mud in the same general area, and in his opinion Dr. Misra's method for exchangeable hydrogen is at fault. The bareness may well reflect not stcrility but 
the activities of swans, boaters, and even limnologists, all easily able to root up large patches of Littorella, Isoetes, and other vegetation from these soft littoral muds. Evidence against the sterility of these muds is also to be found in their possession of abundant surface growths of algae (Lund, private communication). It may therefore be concluded that evidence is lacking for a terminal evolutionary stage of lake sterility, consequent upon a phase of rapid organic production and development of intensely reducing conditions in the lake bottom. Certainly the writer cannot call to mind any case of lake sterility following upon natural eutrophication, though pollution might bring about such a result.

\section{REFERENCES}

Colurns, V. G. 1956. Bacteriology. Ann. Rept. Freshwater Biol. Assoc., 24: 26-28.

Gormam, F. 1953. Chemical studies on the soils and vegetation of waterlogged habitats in the English Lake District. J. Ecol., 41: $345-360$.

Hutciinson, G. E. 1957. A Treatise on Limnology, Vol. 1. John Wiley \& Sons, New York. $1015 \mathrm{pp}$.

Lund, J. W. G. 1954. The seasonal eycle of the plankton diatom, Melosira italica (Ehr.) Kütz. subsp. subarctica O. Müll. J. Ecol., 42: $151-179$

-. 1955. Further observations on the seasonal cycle of Melosira italica (Ehr.) Kütz. subsp. subarclica O. Müll. J. Ecol., 43: $90-102$.

Misna, R. D. 1938. Edaphic factors in the distribution of aquatic plants in the English Lakes. J. Ecol., 26: 411-451.

Mortimer, C. H. 1942. The exchange of dissolved substances between mud and water in lakes. J. Feol., 30: 147-201.

Mundif, J. H. 1956. Invertebrate animals. Ann. Rept. Freshwater Biol. Assoc., 24: 2830.

Tutin, W. 1955. Preliminary observations on a year's cycle of sedimentation in Windermere, England. Mem. Ist. Ital. Idrobiol., suppl. 8: $467-484$. 